\title{
Electrochemical and Spectroscopic Studies on the Interaction between DNA and the Product of Enzyme-catalyzed Reaction of OPD- $\mathrm{H}_{2} \mathrm{O}_{2}-\mathrm{HRP}$
}

\author{
S. Y. Niu, S. S. Zhang, L. B. Ma, and K. Jiao \\ College of Chemistry and Molecular Engineering, Qingdao University of Science and Technologv, Qingdao 266042. China \\ Received February 10. 2004
}

\begin{abstract}
The pure product of 2.3-diaminophenazine was prepared by the enzyme-catalyzed reaction of $o$ phenylenediamine- $\mathrm{H}_{2} \mathrm{O}_{2}$-horseradish peroxidase and characterized by UV/Vis spectroscopy. IR spectroscopy and NMR spectroscopy. The electrochemical behaviour of 2.3-diaminophenazine on the glassy carbon electrode was studied. The interaction between 2.3-diaminophenazine and deosyribonucleic acid was studied by cyclic voltammetry method and UV/Vis spectroscopy. which indicated that the interaction between them is intercalation. The influence of reacting time was also studied. The binding ratio of the 2.3-diaminophenazineDNA complex is calculated to be $1: 2$ and the binding constant is to be $5.07 \times 10^{2} \mathrm{~L} \cdot \mathrm{mol}^{-1}$ at room temperature.
\end{abstract}

Key Words : 2,3-Diaminophenazine. DNA, Cyclic voltanmetry, UV/Vis spectroscopy. Intercalation

\section{Introduction}

Deosyribonucleic acid (DNA) is the most important germ plasm of most organisms. It plays an important role in the process of storing. copying and transmitting germ messages. There are many articles on the interaction between small molecules and DNA since 1960s. Gradually the research has become a field of general interest. ${ }^{l}$ This research is helpful to understand the way of the interaction between DNA and protein. What is more. this is very importent to expound the action mechanism of anticancer drugs, the external selection of drugs and carcinogenesis of the carcinogenic compound. As a poisonous substance. $o$-phenylenediamine (OPD) is irritant to skin. which is considered as the hemolytic action of intermediary metabolism and the formation of methemoglobin. = Different products of the reaction of $\mathrm{H}_{2} \mathrm{O}_{2}$ oxidizing OPD have been reported in literature. The earliest results were reported by Griess ${ }^{3}$ and Knoemagel ${ }^{\dagger}$ respectively. According to their results. the product was 2,3-diaminophenazine (DAP). Later, Gallati and Brodbeck ${ }^{5}$ reported that the product of the reaction of $\mathrm{H}_{2} \mathrm{O}_{2}$ oxidizing $\mathrm{OPD}$ catalyzed by horseradish peroxidase (HRP) was 2,2-diamino azobenzene. Peter ${ }^{6}$ reported that 2.3-diaminophenazine was the product of the reaction of $\mathrm{H}_{2} \mathrm{O}_{2}$ oxidizing $\mathrm{OPD}$, whether catalyzed by HRP or not.

In this article, we prepared the pure product of the reaction of $\mathrm{H}_{2} \mathrm{O}_{2}$ oxidizing OPD catalyzed by HRP. From the experimental results, the oxidation product is 2.3-diaminophenazine. In addition. the interaction between 2,3-diaminophenazine with DNA was studied with spectroscopic and electrochemical methods. It is of great importance to investigate the toxicity mechanism of OPD.

\section{Experimental Section}

Apparatus and reagents. CHI 832 electrochemical

\footnotetext{
Corresponding Author. e-mail: zhangshushiấpublic.qd.sd.cn
}

analyzer was produced by Shanghai Chenhua Instrument Company of China, with a three-electrode system composed of a glassy carbon electrode (GCE) as working electrode, an $\mathrm{Ag} / \mathrm{AgCl}$ as the reference electrode and a platinum electrode as the auxiliary electrode. Cary 50 UV/Vis spectrophotometer was produced by Varian Company of Australian. 510P FT-IR spectrometer was produced by Nicolet Company of the United States. AC-80 FT-NMR spectrometer was produced by Bruker Company of Switzerland.

Salmon sperm DNA was purchased from Huashun Biological Engineering Company of Shanghai. Its concentration was calculated by the absorbance of $260 \mathrm{lmm}(\varepsilon=6600$ $\mathrm{L} \cdot \mathrm{mol}^{-1} \mathrm{~cm}^{-1}$ ). Conmercial HRP ( 250 units per mg enzyme. $\mathrm{RZ}>3.0$ ) was purchased from Xueman Biological Engineering Company of Shanghai. $1.0 \mathrm{~g} \cdot \mathrm{L}^{-1} \mathrm{HRP}$ solution was prepared by dissolving $0.0100 \mathrm{~g}$ of HRP in $10 \mathrm{~mL}$ doubly deionized water. which was stored in a refrigerator at $4{ }^{\circ} \mathrm{C}$. $1.0 \times 10^{-3} \mathrm{~mol} \cdot \mathrm{L}^{-1} \mathrm{H}_{2} \mathrm{O}_{2}$ solution was prepared just before use. $0.05 \mathrm{~mol} \cdot \mathrm{L}^{-1}$ Tris- $\mathrm{HCl}$ buffer solution. $\mathrm{pH} 7.4$ and 0.1 mol $\mathrm{L}^{-1} \mathrm{HOAc}-\mathrm{NaOAc}$ buffer solution. The other reagents were all analytical reagent grade and doubly deionized water was used throughout.

Preparation and characterization of the the enzymecatalyzed product. $2.6 \mathrm{~g}$ OPD was dissolved in $100 \mathrm{~mL}$ water then $9.3 \mathrm{~mL}$ of $30 \% \mathrm{H}_{2} \mathrm{O}_{2}$ solution was added. The $\mathrm{pH}$ of the above solution was adjusted to 4.8 with $0.1 \mathrm{~mol} \mathrm{~L}^{-1}$ HOAc-NaOAc buffer solution. $0.5 \mathrm{~mL}$ of $1.0 \mathrm{~g} \cdot \mathrm{L}^{-1} \mathrm{HRP}$ solution was added to the above solution and set at room temperature for $24 \mathrm{~h}$. The formed precipitate was isolated by decompressing filtration and then washed 3 times with a methanol solution $(30 \%$. v/v). The precipitate was dried and the pure product of the enzrime-catalyzed reaction was obtained. A portion of the pure product was used to record the UV/Vis. FT-IR and ${ }^{13} \mathrm{C}$. NMR spectra.

Studies of the electrochemical behavior of DAP on a glassy carbon electrode. The cyclic voltammetric curve of DAP was recorded on a CHI 832 electrochemical analyzer with a base solution of $\mathrm{pH} 7.4$ Tris- $\mathrm{HCl}$ buffer solution. The 
instrumental parameters are as follows, initial potential: -0.2 $\mathrm{V}$, high potential: $-0.2 \mathrm{~V}$, low potential: $-0.8 \mathrm{~V}$, sample interval: $0.001 \mathrm{~V}$ and quiet time: $2 \mathrm{~s}$.

Electrochemical studies of the interaction between DAP and DNA. $50 \mu \mathrm{L}$ of $2.0 \times 10^{-3} \mathrm{~mol} \cdot \mathrm{I}^{-1}$ DAP was added to $5 \mathrm{ml}$. of $\mathrm{pH} 7.4$ Tris- $\mathrm{HCl}$ buffer solution, to which the different quantities of salmon sperm DNA were added. The cyclic voltammetric figures were recorded on a $\mathrm{CHI} 832$ electrochemical analyzer. The instrumental parameters are as follows, initial potential; $-0.2 \mathrm{~V}$, high potential: $-0.2 \mathrm{~V}$, low potential: $-0.8 \mathrm{~V}$, scan rate: $0.06 \mathrm{~V} \cdot \mathrm{s}^{-1}$, sample interval: 0.001 $V$ and quiet time: $2 \mathrm{~s}$.

UV/Vis spectroscopic studies of the interaction between DAP and DNA. To $10 \mathrm{ml}$. colorimetric tubes were in turn added $50 \mu \mathrm{l}$. of $2.0 \times 10^{-3} \mathrm{~mol} \cdot \mathrm{l}^{-1}$ DAP and different volume of $6.67 \times 10^{-2} \mathrm{~mol} \cdot \mathrm{l}^{-1}$ salmon sperm DNA solution respectively, then diluted to the desired scale with Tris- $\mathrm{HCl}$ buffer solution. The solutions were set for $15 \mathrm{~min}$ at room temperature. The UV/Vis spectra were recorded on a Cary 50 spectrophotometer.

\section{Results and Diseussion}

The spectroscopic characterization of DAP. There are two absorption peaks in the UV/Vis spectrophotometer of DAP in methanol solution. The wavelengths are at 258.0 and $416.0 \mathrm{~nm}$, respectively. The peak at $258.0 \mathrm{~mm}$ is caused by $\pi \rightarrow \pi^{*}$ electron transition of benzene ring. The peak at $416.0 \mathrm{~nm}$ is electron transition, indicating that there are $n \rightarrow \pi^{*}$ electron-offering groups. There are two absorption peaks in the UV/Vis spectrophotometer of phenazine in methanol. The wavelengths are at 248.0 and $363.0 \mathrm{~nm}$, respectively, which are caused by $\pi \rightarrow \pi^{*}$ electron transition. Two aminos at 2,3 position of phenazine, the $N$ atoms of which have unbonded electron pairs, are introduced in 2,3-diaminophenazine and therefore $n \rightarrow \pi^{*}$ electron transition can be formed. Also due to the introduction of aminos, the original two peaks shift to red. The peak at $363 \mathrm{~mm}$ shifts to the visible region and overlaps with the peak of $n \rightarrow \pi^{*}$, and so broad peak in spectrum is obtained. The peak at $248 \mathrm{~nm}$ shifts to $258 \mathrm{~nm}$. The IR absorption bands of the product are identified as follows: Three middle-strong absorption bands at $3435.7,3308.3$ and $3138.0 \mathrm{~cm}^{-1}$, respectively, are the characteristic bands of the coacervation primary amine. These three bands indicate that at least there are two $-\mathrm{NH}_{2}$ groups. The absorption band at $1645.5 \mathrm{~cm}^{-1}$ is the deformation vibration within the plane in primary amine, and that at $1562.0 \mathrm{~cm}^{-1}$ the stretching vibration of $\mathrm{C}=\mathrm{N}$. [ wo strong bands at 1493.1 and $763.9 \mathrm{~cm}^{-1}$ respectively and the middlestrong band at $584.4 \mathrm{~cm}^{-1}$ are the characteristics of phenazine. Absorption band of $\mathrm{C}=\mathrm{C}$ stretching vibration at

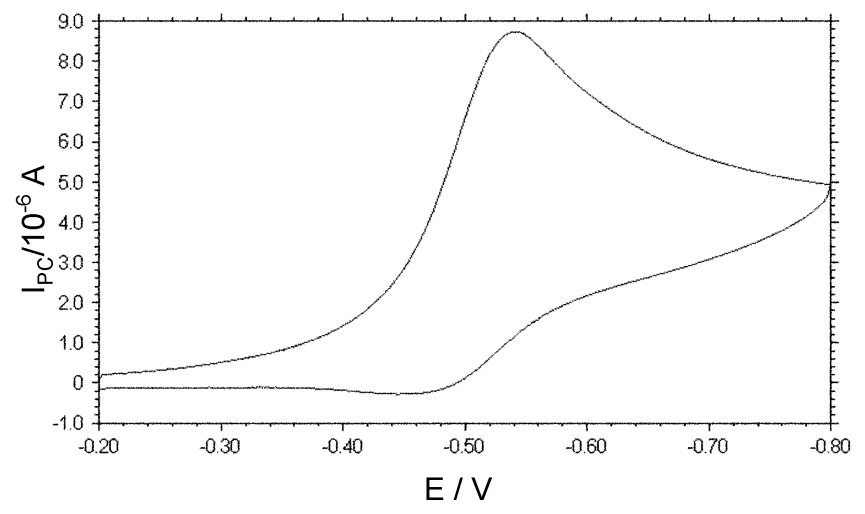

Figure 1, "lhe cyclic voltammetric curve of DAP.

$1493.1 \mathrm{~cm}^{-1}$ is attributed big $\pi$ bonds. The band at 763.9 $\mathrm{cm}^{-1}$ is the deformation vibration out of the plane of the four closed hydrogens in the aromatic ring and that at $843.0 \mathrm{~cm}^{-1}$ the deformation vibration out of the plane of the isolated hydrogen in the aromatic ring; the one at $1338.8 \mathrm{~cm}^{-1}$ is the stretching vibration of $\mathrm{C}-\mathrm{N}=$, the one at $1249.6 \mathrm{~cm}^{-1}$ the stretching vibration of $\mathrm{C}-\mathrm{N}$ in the aromatic ring. Two bands at 584.4 and $490.0 \mathrm{~cm}^{-1}$ are respectively the bending vibrations within and out of the ring plane. The ${ }^{13} \mathrm{C}$ NMR bands of the product are identitied as follows: $105.2(2 \mathrm{C})$, $127.5(5 \mathrm{C}), 129.0(6 \mathrm{C}), 141.5(4 \mathrm{C}), 143.2(3 \mathrm{C}), 145.8(1 \mathrm{C})$ which is coincident to reference. ${ }^{6}$ From the experimental results, the product of the enzyme-catalyzed reaction of $\mathrm{OPD}-\mathrm{H}_{2} \mathrm{O}_{2}$ - $\mathrm{HRP}$ is 2,3-diaminophenazine.

The electrochemical studies of DAP on the glassy carbon electrode.

The electrochemical behavior and the reaction mechanism of DAP on the glass carbon electrode: There are shapely oxidation and reduction peaks of DAP in the base solution of $0.2 \mathrm{~mol} \cdot \mathrm{l}_{-}^{-1} \mathrm{NaH}_{2} \mathrm{PO}_{4}-\mathrm{Na}_{2} \mathrm{HPO}_{4}, 0.2 \mathrm{~mol} \cdot \mathrm{f}^{-1}$ BrittonRobinson, $0.05 \mathrm{~mol} \cdot \mathrm{l}^{-1} \mathrm{Tris}-\mathrm{HCl}$ or $0.1 \mathrm{~mol} \cdot \mathrm{l}^{-1} \mathrm{HOAc}-$ $\mathrm{NaOAc}$ buffer solution, respectively. $0.05 \mathrm{~mol} \cdot \mathrm{L}^{-1}$ Tris- $\mathrm{HCl}$ buffer solution was selected as the base solution according to the peaks of DAP, which was showed in Figure 1.

Under the selected conditions, the influence of $\mathrm{pH}$ to the peak potential of DAP was studied. Both of the potentials of the oxidization peak and the reduction peak shift negatively with the augment of $\mathrm{pH}$, which indicates that $\mathrm{H}^{+}$participates in the electrode reaction. The reduction peak potential has a good linear relation with the $\mathrm{pH}$ value in the range of 6.87.4 , and the slope is -0.0611 . According to the formula ${ }^{7}$ : $-0.059 \times / n=-0.0611$, where $n$ is the number of the electron transfer, $x$ is the hydrogen ion number participating the reaction, and $x=n$. From the experimental results, the redox processes of DAP can be expressed as follows.

The influence of the scan rate to the peak current of DAP:

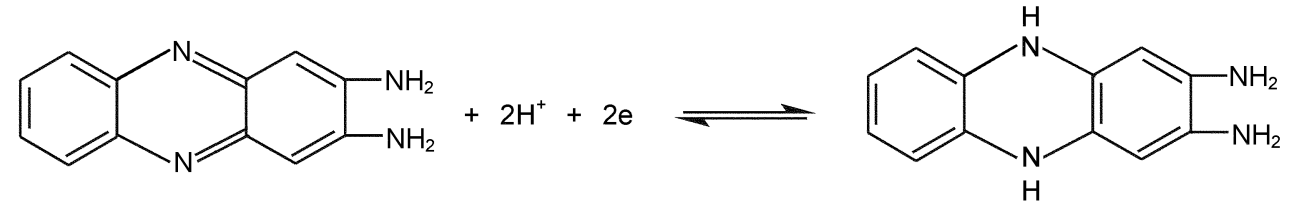




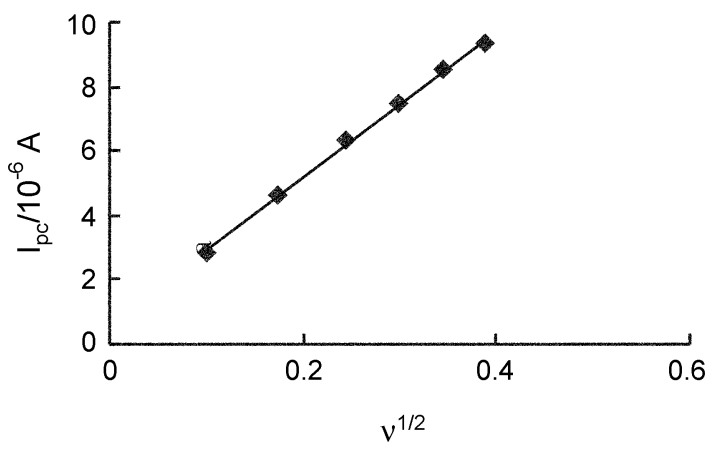

Figure 2. The relationship curve of $\mathrm{I}_{\mathrm{K}}$ vs. $v^{\prime 2}$ of 2.3 -diaminopherlarine.

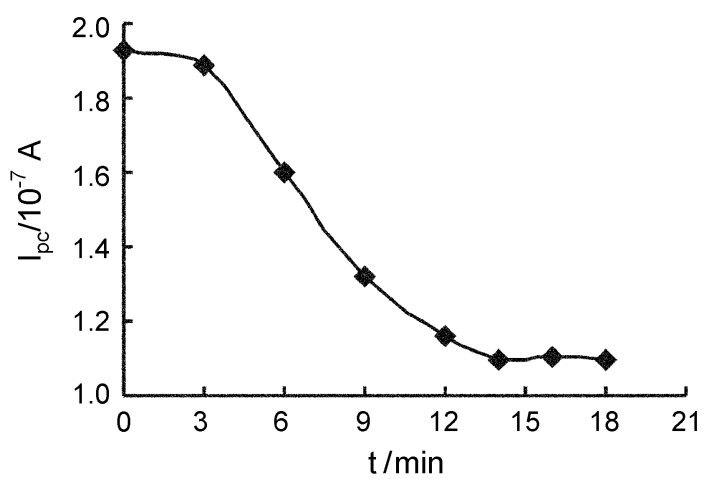

Figure 3. The relationship curve ol $\mathrm{I}_{\mid \mathrm{x}}$ vs. interacting time of [DAP and I $\mathrm{V}$. $\mathrm{A}$.

The relationship curve of $\mathrm{I}_{\mathrm{pc}}$ and $v^{1 ; 2}$ was shown in Figure 2 . According to the results, the $\mathrm{I}_{\mathrm{pc}}$ was linear to $v^{1: 2}$, which indicated that the electrode process of DAP was controlled by the linear diffusion of DAP to the electrode surface.

The electrochemical studies of the interaction between DAP and DNA.

The influence of the reacting time to the peak current of $D A P$ : The variation of the reduction peak current of the mixture solution of DAP and DNA with the reacting time was shown in Figure 3 . The peak current decreases with the reacting time and reaches a constant value after about 15 min, which indicates that the equilibrium of the interaction between DAP and DNA.

The influence of the concentration of DNA to the peak curren of DAP: The cyclic voltammetric curves of DAP solution with different concentration of DNA were showed in Figure 4. The peak current decreased with the increasing of DNA concentration. And there were not other oxidationreduction peaks with the presence of DNA. So nonelectroactive complex was formed between DAP and DNA. There are mainly three non-covalent action modes between small molecule and DNA as followed, intercalation, groove binding and electrostatic action. According to the structure of DAP, DAP' intercalates into the two strands of DNA, and the action mode between DAP and DNA is intercalation.

The binding ratio and the binding constant of the DAPDNA complex: According to the reference, ${ }^{8}$ it is assumed that there is only one complex of DNA-n DAP.

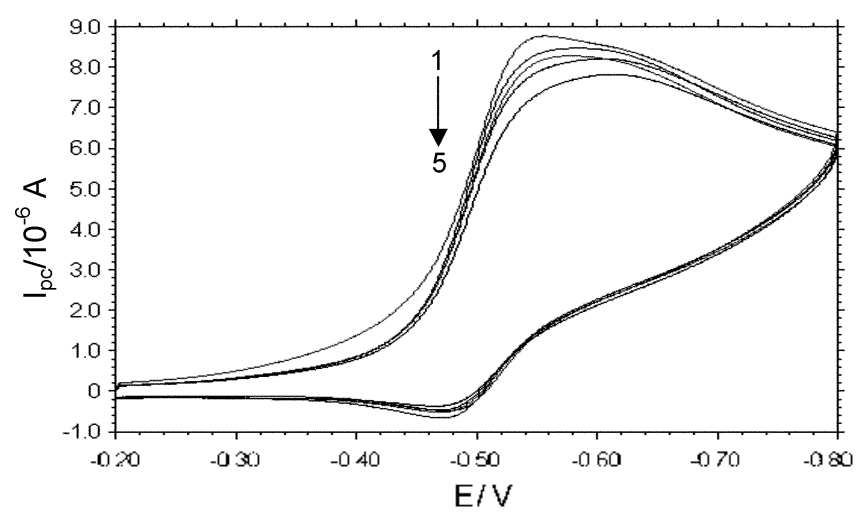

Figure 4. The cyclic voltanmetric curve of the interaction between

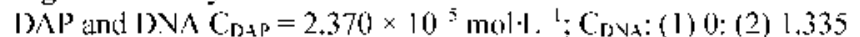
$\times 10^{-6} \mathrm{~mol} \cdot \mathrm{L}^{-1} ;$ (3) $4.005 \times 10^{-1} \mathrm{~mol} \cdot \mathrm{L}^{-1}:$ (4) $6.675 \times 10^{-4} \mathrm{~mol} \cdot \mathrm{L}^{-1}$; (5) $9.345 \times 10^{-1} \mathrm{~mol} \mathrm{~L}^{-1}$.

$$
\begin{aligned}
& \mathrm{DNA}+\mathrm{n} \mathrm{DAP}=\mathrm{DNA}-\mathrm{nDAP} \\
& (\mathrm{n}-1,2,3, \ldots \text { or } 1,1 / 2,1 / 3, \ldots)
\end{aligned}
$$

The equilibrium constant can be expressed as follow,

$$
\beta=\frac{[D N A \quad n D A P \mid}{[D N A][D A P]^{\prime \prime}}
$$

And the following equations can be deduced.

$$
\begin{aligned}
& \Delta \mathrm{l}_{\text {max }}-\mathrm{K}^{\prime} \mathrm{C}_{\mathrm{DNA}} \\
& \Delta \mathrm{l}=\mathrm{K}^{\prime}[\mathrm{DNA} \text {-nDAP] } \\
& {[\mathrm{DNA}]+[\mathrm{DNA}-\mathrm{nDAP}]-\mathrm{C}_{\mathrm{DNA}}} \\
& \Delta \mathrm{l}_{\max }-\Delta \mathrm{I}=\mathrm{K}^{\prime}\left(\mathrm{C}_{\mathrm{DNA}}-[\mathrm{DNA}-\mathrm{nDAP}]\right) \\
& \Delta \mathrm{l}_{\max }-\Delta \mathrm{I}-\mathrm{K}^{\prime}[\mathrm{DNA}] \\
& \frac{\mathrm{l}}{\Delta I}-\frac{\mathrm{l}}{\Delta I_{\max }}+\frac{\mathrm{l}}{\beta \Delta I_{\max }\left[\left.D A P\right|^{\prime \prime}\right.}
\end{aligned}
$$

With different $n$, there are different relationship curves of $\Delta \mathrm{I}^{-1}$ and $[\mathrm{DAP}]^{-11}$. According to equation (7), the relationship curve of $\Delta \mathrm{I}^{-1}$ and [DAP$]^{-t}$ should be a straight line with the suitable $\mathrm{n}$, if there is only one complex formed. From the

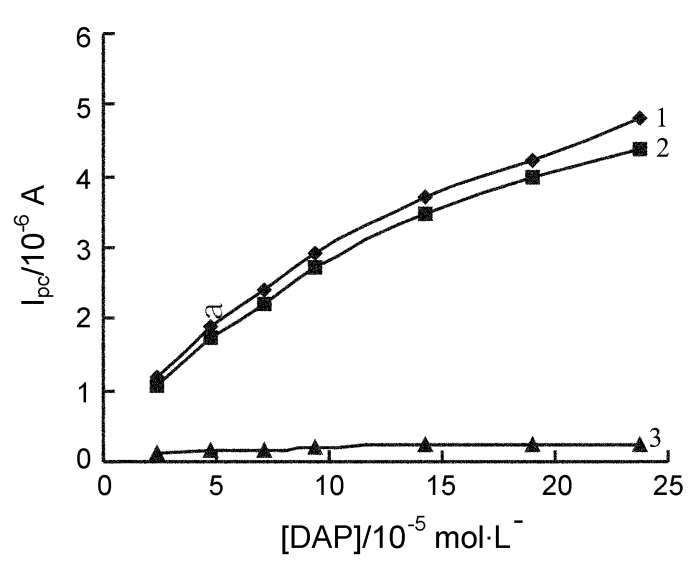

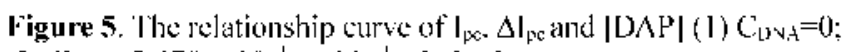
(2) $\mathrm{C} \cdot \mathrm{vN \textrm {L }}=2.670 \times 10^{-4} \mathrm{~mol} \cdot \mathrm{L}^{-1}$; (3) $\mathrm{I}_{\mathrm{pl}}-\mathrm{I}_{\mathrm{p} z}$. 


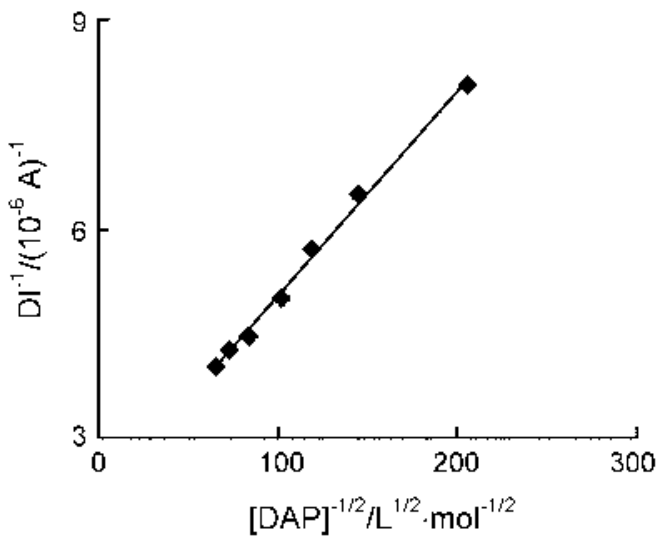

Figure 6. The relationship curve of $\Delta \mathrm{I}^{-1}$ and $[\mathrm{DAP}]^{-1}$.

slope and intercept of the best line, we can calculated the binding constant $\beta$ of the complex of DNA-n DAP.

The relationship curves of the reduction peak current with the concentration of DAP were compared by adding DNA or not. which were shown in Figure 5 . As for $n=1 / 2$, the relationship curve of $\Delta \mathrm{I}^{-1}$ and $[D A P]^{-11}$ is a straight line $(r=0.9973)$, as showed in Figure 6. While for $n=1 / 3$ and 1 , the curve bends up and down, respectively. From the slope and intercept of $\Delta \mathrm{I}^{-1}$ and [DAP] $]^{-1: 2}$, the binding constant $\beta$ was calculated to be $71.2\left[^{1: 2} \cdot \mathrm{mol}^{-1: 2}\right.$, which was corresponding to the equation of DNA $+1 / 2 \mathrm{DAP}=\mathrm{DNA}-1 / 2$ DAP. The binding constant $\beta^{\prime}=\beta^{7}=5.07 \times 10^{3} \mathrm{l} \cdot \mathrm{mol}^{-1}$, which was corresponding to the equation of DAP+2DNA —DAP-2DNA.

The UV/Vis spectroscopic studies of the interaction between DAP and DNA. The UV/Vis spectra of DAP was shown in Figure 7. The absorbance of the mixture of DAP and DNA is not equal to the sum of the absorbance of DAP

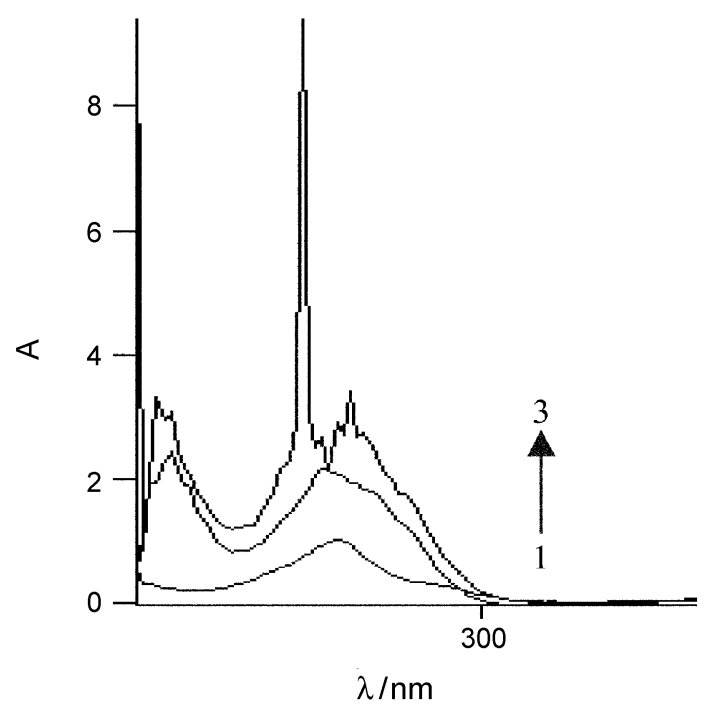

Figure 7. The LV/Vis spectra of DAP and DNA (1) CDip $2.370 \times$

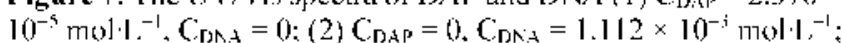
(3) $\mathrm{C}_{\mathrm{DAP}}=2.370 \times 10^{5} \mathrm{~mol} \cdot \mathrm{L}^{\prime}$. $\mathrm{C}_{\mathrm{DNA}}=1.112 \times 10^{\mathrm{s}} \mathrm{mol} \cdot \mathrm{L}^{\prime}$.

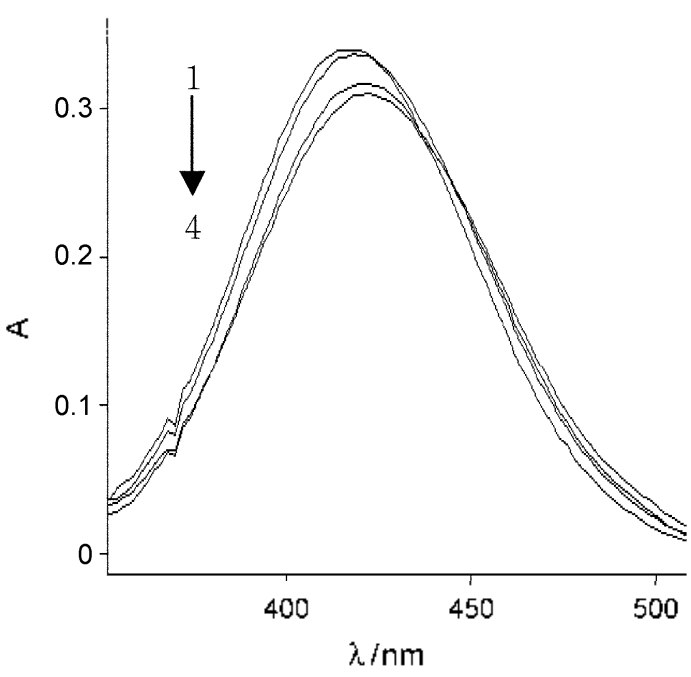

Figure 8. "The eflect of the concentration of IDNA to the Visible

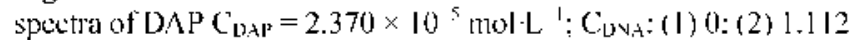
$\times 10^{-3} \mathrm{~mol} \mathrm{~L}^{-1}:$ (3) $2.224 \times 10^{-3} \mathrm{~mol} \mathrm{~L}^{-1}$ : (4) $3.336 \times 10^{-3} \mathrm{~mol} \cdot \mathrm{L}^{-1}$.

and DNA, respectively. Which indicates that DAP could interacted with DNA when mixed together at room temperature.

Figure 8 shows the variation of the visible spectra of DAP solution when added different quantity of DNA. With the increasing of the concentration of DNA, the phenomena of red shift and hypochromic effect of the absorption peak of DAP were observed. What is more, there is an equal absorption point at about $440 \mathrm{~nm}$. According to the reference." the action mode between DAP and DNA is intercalation. The obvious variation of the UV/Vis spectra is caused by the influence of the nearby base pairs of DNA to the electron cloud on the phenazine ring.

Acknowledgements. This work was supported by the National Natural Science Foundation of China (No. 20275020) and the State Key Laboratory Foundation of Electroanalytical Chemistry of Changchun Institute of Applied Chemistry (No. SKLEAC 2004-8).

\section{References}

1. Zhang. R.-Y.: Pang. D.-W.: Cai. R.-X. (hem. I. (hinese tnnersities 1999. 20. 1210.

2. Xit Y. X. Hoxicity of Chemical Sibbstances: Shanghai Science and Technology press: Shanghai. 1991: p 349.

3. Carjess. P. J. Potht. Chen. 1871. 3. 14 i.

4. Knoeviagel. E. J. Prokt. Chem. 1914. 89. 25.

5. Gallati. H.: Brodbeck. H. I. ('/in. (hem. ('lin. Biochem. 1982. 20). 221.

6. Puter, 1. T.: Victor, P. C.: Pave, W. Anal. Biochem. 1987, /65. 230 .

7. Lverse. I.: Lverse. K. I.: Crisham. M. B. Peroridase in Chemistm and Biolog:: C.KC P'ress: Boston. 1991: Vol. 2. p 5.

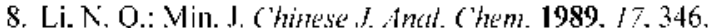

9. Long. E. C.: Barton. J. K. Acc. (hem. Res. 1990. 23.27I. 